\title{
KARAKTERISASI MINUMAN HERBAL CELUP DENGAN PERLAKUAN KOMPOSISI JAHE MERAH : KUNYIT PUTIH, DAN JAHE MERAH : TEMULAWAK
}

\section{CHARACTERIZATION OF DYE HERBAL DRINK WITH COMPOSITION TREATMENT OF RED GINGER : WHITE TURMERIC AND RED GINGER : "TEMULAWAK"}

\author{
Adi Listiana ${ }^{1}$, Herlina ${ }^{2}$ \\ 1) Program Studi Teknologi Pertanian Fakultas Pertanian UNIVED \\ 1) Program Studi Teknologi Pertanian Fakultas Pertanian UNIVED
}

\begin{abstract}
ABSTRAK
Penelitian ini bertujuan untuk mendapatkan karakteristik minuman herbal celup dari jahe merah : kunyit putih dan jahe merah : temulawak. Penelitian ini terdiri dari dua tahap. Tahap pertama bertujuan untuk menentukan aktivitas antioksidan pada variasi perlakuan jahe merah : kunyit putih dan jahe merah : temulawak. Tahap kedua bertujuan untuk menentukan tingkat kesukaan konsumen terhadap minuman herbal celup hasil penelitian. Hasil penelitian menunjukkan bahwa aktivitas antioksidan variasi perlakuan jahe merah dan kunyit putih tertinggi adalah dengan variasi perlakuan $1.5: 0.5 \mathrm{gr}$, yaitu sebesar 83.98 $\%$ RSA, sedangkan nilai terendah pada variasi perlakuan $1.0: 1.0$ gr dengan hasil $82.87 \%$ RSA. Aktivitas antioksidan pada perlakuan jahe merah dan temulawak berkisar antara 86.34\% s/d 87.22 \% RSA, sedangkan tingkat kesukaan panelis terhadap warna berkisar antara 3.60 (suka) s/d 3.95 (suka), Aroma 3.40 (agak suka) s/d 4.00 (suka) dan rasa tidak berpengaruh nyata.
\end{abstract}

Kata Kunci : jahe merah, kunyit putih, temulawak, aktivitas antioksidan

\section{ABSTRACT}

This study aimed to obtain the characteristics of ginger herbal drink red dye : white saffron and red ginger: 'temulawak". This study consisted of two phases. The first stage aims to determine the antioxidant activity in treatment variations of red ginger: white turmeric and red ginger: "temulawak". The second phase aims to determine the level of consumer preferences to drink herbal teabag research results. The results showed that the antioxidant activity of treatment variations of red ginger and turmeric highest white with treatment variations $1.5: 0.5 \mathrm{~g}$, amounting to $83.98 \% \mathrm{RSA}$, while the lowest value in the treatment of variation $1.0: 1.0 \mathrm{~g}$ with $82.87 \% \mathrm{RSA}$ results. The antioxidant activity in red ginger and turmeric treatment ranged from $86.34 \%$ until $87.22 \%$ RSA, while the preference level panelists to colors ranging from 3.60 (like) until 3.95 (like), aroma 3:40 (rather like) until 4.00 (like) and the flavor was not significant.

Keyword : red ginger, white turmeric, "temulawak", antioxidant activity 


\section{PENDAHULUAN}

Seiring dengan perkembangan ilmu pengetahuan dan perubahan gaya hidup masyarakat yang semakin kritis terhadap konsumsi makanan dan minuman untuk menunjang kesehatan, sehingga masyarakat akan lebih selektif dalam memilih suatu produk pangan. Kesibukan dan aktivitas dari masyarakat di era modern menuntut produsen produk pangan menciptakan sebuah inovasi produk pangan yang dapat disajikan dengan cepat dan praktis namun tetap memperhatikan kelengkapan nilai gizinya.

Jahe merah, kunyit putih dan temulawak mengandung komponen bioaktif yang bersifat antioksidan (zat pencegah radikal bebas yang menimbulkan kerusakan pada sel-sel tubuh), dan dapat berinteraksi dengan reaksi-reaksi fisiologis, sehingga mempunyai kapasitas antimikroba, anti pertumbuhan sel kanker, dan sebagainya.

Senyawa fitokimia sebagai senyawa kimia yang terkandung dalam tanaman mempunyai peranan yang sangat penting bagi kesehatan termasuk fungsinya dalam pencegahan terhadap penyakit degeneratif. Beberapa senyawa fitokimia yang diketahui mempunyai fungsi fisiologis adalah karotenoid, fitosterol, saponin, glikosinolat, polifenol, inhibitor protease, monoterpen, fitoestrogen, sulfida, dan asam fitat.

Berdasarkan data dari Badan Pusat Statistik Indonesia tahun 2013, produksi jahe mencapai 232.616.356 kg, kunyit $113.344 .692 \mathrm{~kg}$, dan temulawak 28.262.035 kg. Produksi yang besar tersebut harus dimanfaatkan sebaikbaiknya agar nantinya dapat memberikan arti bagi pengembangan pangan fungsional di Indonesia. Minuman herbal merupakan salah satu produk minuman campuran tanaman herbal yang memiliki khasiat dalam membantu pengobatan suatu penyakit atau sebagai minuman penyegar tubuh.

Diversifikasi terhadap suatu produk pangan perlu dilakukan untuk lebih meningkatkan potensi gizi dan senyawa aktif yang terkandung dalam produk pangan tersebut. Sehingga produk tersebut akan lebih mempunyai nilai tambah baik dari segi citarasa maupun manfaatnya dalam menjaga kesehatan tubuh manusia. Minuman herbal dari campuran jahe merah, kunyit putih dan jahe merah, temulawak merupakan salah satu bentuk diversifikasi produk untuk mengoptimalkan pemanfaatan tanaman herbal tradisional. Pengolahan lebih lanjut diharapkan dapat meningkatkan nilai tambah bagi jahe merah, kunyit 
putih dan temulawak secara organoleptik. (Winarsi, Heri. 2007).

Berdasarkan penelitian yang dilakukan oleh Wijayakusuma et al . (1997) bahwa kandungan senyawa kimia di dalam tanaman rempah di antaranya adalah alkaloid, flavonoid, kurkumin, minyak atsiri, saponin, pati, tanin, steroid/triterpenoid, dan lemak . Berdasarkan sifat kimianya maka beberapa kelompok senyawa yang mempunyai kemungkinan untuk berperan dalam mengatasi efek anti peradangan, antioksidan, antibakteri, imunostimulan, dan sebagai kolagogum dapat dikombinasikan dengan jenis rempah lainya. Penambahan konsentrasi campuran ekstrak jahe merah dan temulawak telah terbukti mampu meningkatkan aktivitas antioksidan dibandingkan bila dipergunakan secara terpisah, sehingga pencampuran ekstrak rempah ke dalam produk minuman herbal ini diharapkan juga mampu memberikan kombinasi antioksidan dengan aktivitas yang lebih tinggi dibandingkan bila hanya digunakan secara terpisah. Wijayakusuma, H.M. (2007)

Antioksidan dalam bahan pangan dan minuman dipercaya dapat menyembuhkan berbagai penyakit antara lain kanker, tumor, jantung, ginjal dan kencing manis. Menurut Kardono dan
Dewi (1998) senyawa-senyawa yang telah diketahui mampu bersifat antioksidan antara lain stilbena, asamasam galat, elagat, kumarat, flavonoid dan kurkuminoid. Kurkuminoid terdapat dalam rimpang jahe merah (Yuliani, 2009), temulawak (Wijayakusuma, 2007) dan kunyit putih (Kriswanto, 2011). Rimpang tersebut biasa dikonsumsi sebagai bahan baku minuman yang menyehatkan. Dalam pengolahan minuman instan komponen pangan fungsional tersebut umumnya diekstraksi dengan air, dengan demikian pengolahan minuman instan dengan proses ekstraksi dengan air dapat dilakukan pada suhu di bawah 100oC, sehingga kerusakan komponen antioksidan dapat dicegah. (Jayaprakasha dkk. 2005).

Ekstraksi komponen antioksidan (minyak atsiri) dalam jahe merah, temulawak dan kunyit dengan pelarut organik merupakan salah satu alternatif yang dapat meningkatkan kadar antioksidan. Menurut Jayaprakasha dkk. (2005) minyak atsiri tersebut dapat diekstraksi menggunakan pelarut dengan sangat efektif. Cara mengekstraksi antioksidan alami tergantung jenis antioksidan yang akan diekstraksi dan pelarut yang digunakan untuk mengekstraksi harus sesuai dengan polaritas senyawa yang diekstraksi. Selain itu pemilihan jenis 
pelarut dipengaruhi oleh kekhasan bahan dan stabilitas substrat.

Jahe merah (Zingiber officinale Rosc.) sudah lama dikenal dapat menyembuhkan berbagai macam penyakit, dibandingkan dengan jahe gajah atau jahe empirit. Meskipun demikian, kebanyakan orang umumnya lebih mengenal jahe gajah, yakni sebagai bumbu dapur, rempah-rempah, dan bahan obat-obatan. berdasarkan penelitian para ahli, dalam maupun manca negara, jahe memiliki efek farmakologis yang berkhasiat sebagai obat dan mampu memperkuat khasiat obat yang dicampurkannya. Dari ketiga jenis jahe yang ada jahe merah yang lebih banyak digunakan sebagai obat, karena kandungan minyak atsiri dan oleoresinnya paling tinggi dibandingkan dengan jenis jahe yang lain sehingga lebih ampuh menyembuhkan berbagai macam penyakit (Tim Lentera, 2002)

Kunyit putih, termasuk jenis kunyit yang bentuknya seperti kunyit biasa. Perbedaanya terletak pada warna rimpang dan aromanya. Pada kunyit biasa rimpangnya berwarna oranye dan beraroma sengir, sedangkan pada kunyit putih rimpangnya berwarna hijau kekuningan dan baunya harum seperti mangga mangkal. Kunyit putih merupakan tanaman semak yang tumbuh semusim dan memiliki tinggi $30-70 \mathrm{~cm}$. Batangnya berpelepah, lunak, membentuk rimpang, dan berwarna hitam keabu-abuan. Daunnya tunggal, lanset, ujung runcing, pangkal berpelepah, tepi rata, ibu tulang daun menonjol, panjang $70 \mathrm{~cm}$, berwarna hijau muda. Bunganya majemuk, berbentuk tabung, kelopak lanset, memiliki panjang 4-8 cm, lebar 23,5 cm, mahkota panjang 10-19 cm, benang sari dan putik kecil, berwarna putih. Kunyit putih memiliki akar serabut dan berwana putih. Kunyit putih merupakan salah satu tanaman obat keluarga (toga). Kunyit putih memiliki rasa yang lebih getir dibandingkan dengan kunyit biasa. Namun aroma yang dimiliki lebih khas dan kuat lantaran kandungan minyak atsirinya lebih banyak. Kunyit putih diketahui banyak mengandung minyak atsiri yang terdiri atas curdione dan curcumol. Memiliki sifat antioksidan yang dapat menahan zat radikal bebas penyebab tumbuhnya sel kanker, antiinflamasi (peradangan) serta dapat meningkatkan sel darah merah (Kriswanto, 2011).

Temulawak merupakan tanaman tahunan (perennial) yang tumbuh berumpun, berbatang basah yang merupakan batang semu yang terdiri atas gabungan beberapa pangkal daun yang terpadu. Tinggi tumbuhan temulawak sekitar $2 \mathrm{~m}$. 
daun berbentuk memanjang sampai lanset, panjang daun $50-55 \mathrm{~cm}$ dan lebarnya sekitar $15 \mathrm{~cm}$, warna daun hijau tua dengan garis coklat keunguan. Tiap tumbuhan mempunyai 2 helai daun. Tumbuhan temulawak mempunyai ukuran rimpang yang besar dan bercabang-cabang. Rimpang induk berbentuk bulat atau bulat telur dan disampingnya terbentuk 3-4 rimpang cabang yang memanjang. Warna kulit rimpang coklat kemerahan atau kuning tua, sedangkan warna daging rimpang kuning jingga atau jingga kecoklatan. Perbungaan lateral yang keluar dari rimpangnya, dalam rangkaian bentuk bulir dengan tangkai yang ramping. Bunga mempunyai daun pelindung yang banyak dan berukuran besar, berbentuk bulat telur sungsang yang warnanya beraneka ragam (Wijayakusuma, 2007).

Karena manfaat yang besar, rimpang temulawak telah digunakan secara luas dalam rumah tangga dan industri. Penggunaan rimpang temulawak dalam bidang industri antara lain industri makanan, minuman, obat-obatan, tekstil dan kosmetik. Peningkatan penggunaan temulawak dalam industri obat-obatan memerlukan teknik pengolahan yang baik sehingga mutunya dapat meningkat. (Bombaderlli, 1991; Vijesekera, 1991 dalam Sembiring dkk., 2006)
Antioksidan merupakan zat kimia yang secara bertahap akan teroksidasi dengan adanya efek seperti cahaya, panas, logam peroksida atau secara langsung bereaksi dengan oksigen. Ada dua macam antioksidan, yaitu antioksidan alam dan antioksidan sintesis. Sebagai contoh $\alpha$ tokoferol (vitamin E) merupakan antioksidan alam yang terdapat dalam lemak dan minyak yang diperoleh dari biji tanaman (Zapsalis,1985). Kurkumin yang terdapat pada temulawak juga adalah antioksidan alam yang lain dimana aktifitasnya lebih besar dibanding dengan $\alpha$ tokoferol jika diuji dalam minyak (Wahyudi, 2006).

Kurkumin sendiri merupakan molekul dengan kadar polifenol yang rendah namun memiliki aktivitas biologi yang tinggi antara lain potensi sebagai antioksidan (Jayaprakasha dkk., 2005). Selain kurkumin, senyawa fenol yang terdapat pada temulawak bisa berfungsi sebagai antioksidan karena kemampuannya meniadakan radikalradikal bebas dan radikal peroksida sehingga efektif dalam menghambat oksidasi lipida (Kinsella et al., 1993).

Tujuan dilakukannya penelitian ini adalah untuk menganalisis pengaruh formulasi jahe merah, kunyit putih dan jahe merah, temulawak terhadap aktivitas 
antioksidan dan sifat organoleptik minuman celup yang dihasilkan

\section{METODE PENELITIAN}

\section{Bahan dan Alat}

Bahan yang digunakan dalam penelitian ini adalah jahe merah (Zingiberofficinale Rosc), kunyit putih (Kaempferiarotunda L), temulawak (Curcumaxanthorriza Roxb), dan kantong minuman celup kosong, Alat yang digunakan dalam penelitian ini adalah timbangan analitik, kompor gas, gelas ukur plastik, blender, wajan, pisau, telenan, wadah plastik, plastik, cawan, dan alat uji aktivitas antioksidan.

\section{Cara Penelitian}

Penelitian ini dilakukan dalam dua tahap, yaitu penyiapan serbuk jahe merah, kunyit putih, temulawak dan pembuatan minuman herbal celup.

Tahap awal penelitian ini adalah penyiapan serbuk jahe merah, kunyit putih dan temulawak, dilanjutkan dengan tahap penyiapan minuman herbal celup, dengan langkah-langkah sebagai berikut :

1. Dicampurkan dan dimasukkan serbuk kedalam kantong celup kosong dengan variasi perlakuan serbuk jahe merah : kunyit putih yang terdiri dari tiga taraf, yaitu 1,00 gr : $1,00 \mathrm{gr}, 1,25 \mathrm{gr}$ : $0,75 \mathrm{gr}, 1,50 \mathrm{gr}: 0,50 \mathrm{gr}$ dan variasi perlakuan serbuk jahe merah : temulawak yang terdiri dari tiga taraf juga, yaitu 1,00 gr : 1,00 gr, 1,25 gr : 0,75 gr, 1,50 gr : 0,50 .

2. Kantong celup yang telah diisi serbuk di tutup dengan menggunakan alat perekat plastik (Sealer).

3. Dilakukan uji organoleptik berupa uji warna, rasa dan aroma untuk melihat tingkat kesukaan panelis terhadap seduhan minuman herbal celup yang dihasilkan.

4. Dilakukan uji aktivitas antioksidan terhadap seduhan minuman herbal celup yang dihasilkan.

\section{Analisis Penelitian}

Analisis penelitian yang dilakukan adalah analisis yang terdiri dari aktivitas antioksidan (Blois, 1958) dan uji organoleptik (Soekarto, 1990). Sifat organoleptik yaitu uji kesukaan terhadap parameter penampakan, warna, aroma, dan rasa dengan menggunakan 20 panelis. Bahan disajikan secara acak dengan kode tertentu. Pengujian merupakan uji kesukaan secara hedonik dengan skala penilaian $1-5$ yaitu : (5) sangat suka, (4) suka, (3) agak suka, (2) tidak suka, (1) sangat tidak suka.

Analisis data dilakukan berdasarkan data hasil pengujian uji organoleptikdianalisis secara deskriptif berdasarkan skor modus dan persentase penerimaanpanelis dari 
masing-masing taraf perlakuan serta uji statistik dengan menggunakan tabek analisis varians (ANOVA), selanjutnya untuk mengetahui sejauh mana perbedaan dari masing-masing perlakuan dilakukan uji Duncan taraf $5 \%$ (LSR Test) untuk mengetahui mana yang berbeda nyata (Sudarmadji, dkk. 1997).

\section{HASIL DAN PEMBAHASAN}

Minuman herbal celup ini merupakan minuman yang dapat disajikan secara cepat dan praktis dengan kandungan gizi yang cukup tinggi yaitu kandungan antioksidan. Berdasarkan hasil penelitian pembuatan serbuk jahe merah, kunyit putih dan temulawak, dalam 500 gram masing-masing bahan didapatkan berat serbuk berturut-turut yaitu : 49.5 gr, 43,7 gr dan 37,9 gr. Pembuatan minuman herbal celup dalam kantong minuman celup kosong diisi seberat 2 gr dengan variasi perlakuan yang berbeda-beda, dan selanjutnya kantong celup yang sudah diisi ditutup dengan menggunakan alat perekat plastik (sealer).

Hasil uji aktivitas antioksidan (Tabel 1) minuman jahe merah dan kunyit putih didapatkan hasil bahwa variasi perlakuan tidak berpengaruh nyata terhadap aktivitas antoksidan yang dihasilkan, dan hasil uji aktivitas antioksidan minuman jahe merah dan temulawak juga didapatkan hasil bahwa variasi perlakuan tidak berpengaruh nyata terhadap aktivitas antoksidan yang dihasilkan. Hal tersebut dikarenakan oleh besarnya kandungan minyak atsiri jahe merah, kunyit putih dan temulawak, kandungan minyak atsiri berturut-turut sebesar 1-4 \% (jahe merah), 1-3 \% (kunyit putih) dan 1$2 \%$ (temulawak) Suwiah (1991). Minyak atsiri pada jahe merah banyak terkandung senyawa fenolik seperti gingerol dan shogaol yang mempunyai aktivitas antioksidan yang tinggi melebihi aktivitas antioksidan vitamin E (Jayaprakasha. G.K 2006). Sedangkan minyak atsiri pada kunyit putih terdiri dari keton, sesquiterpen, turmeron, tumeon, zingiberen, felandren, sabinen, borneol, dan sineil. Senyawa tersebut memiliki kandungan RIP (Ribosom Inacting Protein), zat antioksidan dan zat antikurkumin (Setyowati, A 2006). Menurut Jayaprakasha. G.K (2006) senyawa-senyawa minyak atsiri pada temulawak seperti isofuranogermakren, trisiklin, allo-aromadendren, germaken, xanthorrizol dan ar-turmeron telah diketahui mampu bersifat antioksidan. 
Tabel 1. Nilai Rata-Rata Uji Aktivitas Antioksidan.

\begin{tabular}{ccc}
\hline Perlakuan & \multicolumn{2}{c}{ Aktivitas Antioksidan } \\
\hline $\begin{array}{c}\text { Jahe merah : (kunyit } \\
\text { putih / temulawak) }\end{array}$ & $\begin{array}{c}\text { Kunyit Putih } \\
(\% \text { RSA })\end{array}$ & $\begin{array}{c}\text { Temulawak } \\
(\% \text { RSA })\end{array}$ \\
\hline $1.00: 1.00$ & $82.87 \mathrm{~cd}$ & $87.22 \mathrm{a}$ \\
$1.25: 0.75$ & $83.53 \mathrm{~cd}$ & $86.97 \mathrm{ab}$ \\
$1.50: 0.50$ & $83.98 \mathrm{bcd}$ & $86.34 \mathrm{abc}$ \\
\hline
\end{tabular}

Keterangan : angka yang diikuti kode huruf yang berbeda menunjukkan adanya beda nyata pada taraf signifikansi $5 \%$. Atribut mutu : antara (5) sangat suka, (4) suka, (3) agak suka, (2) tidak suka, (1) sangat tidak suka.

Tabel 2. Nilai Rata-Rata Uji Kesukaan Warna

\begin{tabular}{ccc}
\hline Perlakuan & \multicolumn{2}{c}{ Kesukaan terhadap Warna } \\
\hline $\begin{array}{c}\text { Jahe merah : (kunyit } \\
\text { putih / temulawak) }\end{array}$ & $\begin{array}{c}\text { Kunyit Putih } \\
(\% \text { RSA })\end{array}$ & $\begin{array}{c}\text { Temulawak } \\
(\% \mathrm{RSA})\end{array}$ \\
\hline $1.00: 1.00$ & $3.95 \mathrm{a}$ & $3.60 \mathrm{bcd}$ \\
$1.25: 0.75$ & $3.65 \mathrm{ab}$ & $3.45 \mathrm{~cd}$ \\
$1.50: 0.50$ & $3.60 \mathrm{abc}$ & $2.55 \mathrm{~cd}$ \\
\hline
\end{tabular}

Keterangan : angka yang diikuti kode huruf yang berbeda menunjukkan adanya beda nyata pada taraf signifikansi $5 \%$. Atribut mutu : antara (5) sangat suka, (4) suka, (3) agak suka, (2) tidak suka, (1) sangat tidak suka.

Tabel.3 Nilai Rata-Rata Uji Kesukaan Aroma

\begin{tabular}{ccc}
\hline Perlakuan & \multicolumn{2}{c}{ Kesukaan terhadap Aroma } \\
\hline $\begin{array}{c}\text { Jahe merah : (kunyit } \\
\text { putih / temulawak) }\end{array}$ & $\begin{array}{c}\text { Kunyit Putih } \\
(\% \mathrm{RSA})\end{array}$ & $\begin{array}{c}\text { Temulawak } \\
(\% \mathrm{RSA})\end{array}$ \\
\hline $1.00: 1.00$ & $4.00 \mathrm{a}$ & $3.40 \mathrm{bcd}$ \\
$1.25: 0.75$ & $3.65 \mathrm{ab}$ & $3.35 \mathrm{bcd}$ \\
$1.50: 0.50$ & $3.60 \mathrm{abc}$ & $3.40 \mathrm{bcd}$ \\
\hline
\end{tabular}

Keterangan : angka yang diikuti kode huruf yang berbeda menunjukkan adanya beda nyata pada taraf signifikansi $5 \%$. Atribut mutu : antara (5) sangat suka, (4) suka, (3) agak suka, (2) tidak suka, (1) sangat tidak suka.

Tabel.4 Nilai Rata-Rata Uji Kesukaan Rasa

\begin{tabular}{ccc}
\hline Perlakuan & \multicolumn{2}{c}{ Kesukaan terhadap Rasa } \\
\hline $\begin{array}{c}\text { Jahe merah : (kunyit } \\
\text { putih / temulawak) }\end{array}$ & $\begin{array}{c}\text { Kunyit Putih } \\
(\% \text { RSA })\end{array}$ & $\begin{array}{c}\text { Temulawak } \\
(\% \text { RSA })\end{array}$ \\
\hline $1.00: 1.00$ & $3.15 \mathrm{a}$ & $3.25 \mathrm{a}$ \\
$1.25: 0.75$ & $3.10 \mathrm{a}$ & $3.50 \mathrm{a}$ \\
$1.50: 0.50$ & $3.10 \mathrm{a}$ & $3.15 \mathrm{a}$ \\
\hline
\end{tabular}

Keterangan : angka yang diikuti kode huruf yang berbeda menunjukkan adanya beda nyata pada taraf signifikansi $5 \%$. Atribut mutu : antara (5) sangat suka, (4) suka, (3) agak suka, (2) tidak suka, (1) sangat tidak suka. 
Aktivitas antioksidan jahe merah, kunyit putih dan jahe merah, temulawak menunjukkan perbedaan yang nyata. Variasi perlakuan jahe merah dan temulawak mempunyai aktivitas antioksidan tinggi yang disebabkan temulawak mengandung kurkumin dan demotoksikurkumin yang aktivitas antioksidanya tinggi (Khatun, 2006), sehingga semakin besar variasi perlakuanya semakin tinggi pula aktivitas antioksidan yang dihasilkanya. Aktivitas antioksidan jahe merah dan kunyit putih lebih rendah di bandingkan variasi perlakuan jahe merah dan temulawak dikarenakan kunyit putih selain mengandung kurkumin dan demotoksikurkumin, juga mengandung bisdemotoksikurkumin, sehingga walaupun kadar antioksidanya semakin besar akan tetapi aktivitas antioksidanya mengalami penurunaan. Hal ini sesuai dengan penelitian (Suryanto dkk. 2005) bahwa ada kecenderungan penurunan aktivitas penangkal radikal dikarenakan bisdemotoksikurkumin merupakan antioksidan yang mudah larut dan merupakan antioksidan pemutus rantai, penangkal radikal peroksil paling potensial diikuti oleh tokoferol.

Hasil kesukaan warna seduhan minuman jahe merah, kunyit putih dan temulawak pada semua rasio disukai panelis (Tabel
2), hal ini disebabkan adanya komponen kimia yang dominan yaitu kurkumin pada jahe merah, kunyit putih dan temulawak. Hasil uji kesukaan warna minuman jahe merah, kunyit putih dan jahe merah, temulawak menunjukkan perbedaan yang nyata pada minuman jahe merah, kunyit putih dan jahe merah, temulawak. Hal ini disebabkan karena perbedaan besarnya komponen kurkumin pada kunyit putih dan temulawak. Menurut (Setyowati dkk., 2009) serbuk kunyit putih dan temulawak kering mengandung kurkumin berturut-turut sebesar 4.866 dan 22.992 ppm. Semakin besar kandungan kurkumin menyebabkan warna kuning nampak gelap sehingga nilai warna kuningnya menurun, dan nilai kecerahanya lebih rendah.

Aroma minuman herbal celup jahe merah, kunyit putih dan temulawak pada semua rasio disukai panelis, hal tersebut dikarenakan panelis sudah terbiasa dengan aroma jahe merah, kunyit putih dan temulawak, seperti disajikan pada Tabel 3. Menurut Suwiah (1991) Jahe merah, kunyit putih dan temulawak mempunyai aroma yang berbau tajam yang berasal dari besarnya kandungan minyak atsiri. Kandungan minyak atsiri jahe merah, kunyit putih dan temulawak berturut-turut sebesar $1-4 \quad \% \quad$ (jahe merah), 1-3\% (kunyit putih) dan 3-12\% (temulawak) Suwiah (1991). 
Hasil uji kesukaan rasa minuman jahe merah, kunyit putih dan jahe merah, temulawak berkisar antara 3.10 sampai 3.50 (agak suka) (Tabel 4). Rasa minuman herbal celup jahe merah, kunyit putih dan temulawak pada semua rasio agak disukai panelis. Hal tersebut dikarenakan rasa getir dan agak pedas pada perlakuan jahe merah dan temulawak. Menurut Suwiah (1991) rasa getir terjadi karena fraksi pati, minyak atsiri dan kurkuminoid terekstraksi lebih banyak. Rasa pahit dan agak pedas pada perlakuan jahe merah dan kunyit putih pada semua rasio agak disukai panelis.

\section{SIMPULAN}

Formulasi jahe merah dan kunyit putih 1,5 : 0,5 gr mempunyai aktifitas antioksidan tertinggi $83,98 \%$ RSA, formulasi jahe merah dan temulawak 1 : 1 gr mempunyai aktivitas antioksidan tertinggi $87,22 \%$ RSA. Untuk uji organoleptik, formulasi perlakuan $1: 1 \mathrm{gr}$ disetiap variasi perlakuan antara jahe merah, kunyit putih dan jahe merah, temulawak lebih disukai panelis dibandingkan dengan formulasi perlakuan lainya.

Hasil aktivitas antioksidan variasi perlakuan jahe merah dan kunyit putih tertinggi pada variasi perlakuan $1.5: 0.5$ gr sebesar $83.98 \%$ RSA dan aktivitas antioksidan terendah pada variasi perlakuan 1.0 : 1.0 gr dengan aktivitas antioksidan $82.87 \%$ RSA. Pada variasi perlakuan jahe merah dan temulawak aktivitas antioksidan tertinggi pada variasi perlakuan $1.0: 1.0 \mathrm{gr}$ sebesar $87.22 \%$ RSA dan aktivitas antioksidan terendah pada variasi perlakuan $1.5: 0.5$ gr dengan aktivitas antioksidan 86.34\% RSA.

Berdasarkan uji kesukaan warna, variasi perlakuan komposisi jahe merah, kunyit putih, perlakuan $1.0: 1.0$ gr lebih disukai panelis dengan nilai 3.95 (suka) dan variasi jahe merah, temulawak pada perlakuan 1.0 : 1.0 gr dengan nilai 3.60(suka). Berdasarkan uji kesukaan aroma, variasi perlakuan komposisi jahe merah, kunyit putih $1.0: 1.0$ gr lebih disukai panelis dengan nilai 4.00 (suka) dan variasi jahe merah, temulawak pada perlakuan $1.0: 1.0$ gr dengan nilai 3.40 (agak suka). Berdasarkan uji kesukaan rasa didapatkan perlakuan yang tidak berpengaruh nyata, dengan nilai variasi perlakuan jahe merah, kunyit putih, dan jahe merah, temulawak berkisar antara 3.10 (agak suka) sampai 3.50 (agak suka).

\section{DAFTAR PUSTAKA}

Blouis, M.S. 1958. Antioxidant Determinations by The Use of a Stable Free Radical Nature. 1199-1200.

Jayaprakasha, G. K., Jaganmohan Rao. L., dan Sakariah K. K. 2006. 
Antioxidant Activities of Curcumin, Demethoxycurcumin and Bisdemethoxycurcumin. Food Chemistry 98. 720-724.

Kinsella, J.E. Frankel, E. German, B. and Kanmer, J. 1993. Possible Mekanisme for the Protective role of Antioxidants in Wine and Plant Foods J Food Technology. 4:5-89.

Kriswanto, M. 2011. Tanaman Berkhasiat Antioksidan. Penebar Swadaya. Jakarta.

Sembiring, Bagem $\mathrm{Br}$; Ma'mun ; Ginting, Edi Imanuel. 2006. Pengaruh Kehalusan Bahan dan Lama Ekstraksi terhadap Mutu Ekstrak Temulawak (Curcuma xanthorriza Roxb) . Buletin Penelitian Tanaman Rempah dan Obat ; 17 (2) 2006: 53-58

Setyowati, A. Suryani, Ch.L. dan Wazyka, A. 2009. Pengaruh Perlakuan Pendahuluan terhadap Kecepatan Pengeringan dan Kadar Antioksidan Bubuk Zingiberaceae (Jahe Merah, Temulawak, Kunyit). Prosiding Seminar Nasional 2009. Pengembangan Teknologi Berbasis Bahan Baku Lokal. hal 53-59. Yogyakarta.

Soekarto, S.T. 1990. Dasar-Dasar Pengawasan dan Standarisasi Mutu Pangan. Jurusan Teknologi Pangan dan Gizi. Departemen Pendidikan dan Kebudayaan. Direktorat Jenderal Pendidikan Tinggi. Pusat Antar Universitas Pangan dan Gizi Institut Pertanian Bogor. Bogor.

Suryanto, E. Raharjo, S., Sastrohamidjojo, H. dan Tranggono 2005. Aktivitas Antioksidan dan Stabilitas Ekstrak Andaliman
(Zanthoxylum acanthopodium DC) terhadap Panas, Cahaya Fluoresen dan Ultraviolet. Agritech 25: 63-69.

Suwiah, A. 1991. Pengaruh Perlakuan Bahan dan Jenis Pelarut yang Digunakan pada Pembuatan Temulawak Instant terhadap Rendemen dan Mutunya. Skripsi. Fakultas Teknologi Pertanian. Institut Pertanian Bogor. Bogor.

Tim Lentera. 2002. Uji Efek Antiinflamasi dari Kombinasi Ekstrak Rimpang Jahe Merah (Zingiber officinale Rosc.) dan Ekstrak Rimpang Kunyit (Curcuma domestica Val.) dalam Sediaan Topikal pada Mencit Jantan. Skripsi. Medan: Fakultas Farmasi. Universitas Sumatera Utara.

Wahyudi, Agus. 2006. Pengaruh Penambahan Kurkumin dari Rimpang Temu Giring pada Aktifitas Antioksidan Asam Askorbat dengan Metode FTC. Akta Kimindo Vol. 2 No. 1 Oktober 2006: 37 - 40. ITS. Surabaya.

Wijayakusuma, H.M. 2007. Tanaman Berkhasiat Obat di Indonesia. Jilid IV. Cetakan II. Jakarta: Pustaka Kartini. Hal. 7.

Winarsi, Heri. 2007. Antioksidan Alami dan Radikal Bebas. Kanisius. Yogyakarta

Yuliani, S, Desmawarni dan N. Harimurti. 2009. Pengaruh Laju Alir Umpan dan Suhu Inlet Spray Drying pada Karakteristik Mikrokapsul Oleoresin Jahe. J. Pascapanen 4: 18-26 Zapsalis, C.A.Beck. 1985. Food Chemistry and Nutritional Biochemistry. John Willey and Sons, New York. hal 453-454. 